\title{
Agricultural Land Suitability Analysis for Maize Crop by Using GIS Technology in Case of Debub Gondar Zone, Ethiopia
}

\author{
Tilahun Abie Fetene \\ Department of Geography and Environmental Studies, Kebri Dehar University, Kebri Dehar, Ethiopia
}

\begin{abstract}
Food security is the current problem that affects the socio economic standard and living condition of the society. Land suitability analysis is a method of land evaluation which measures the degree of appropriateness of land for a certain use. The aim of this study was to identify and delineate the land that can best support maize production by using GIS technology. The study was carried out in Debub Gondar zone in Ethiopia. Even though agriculture is the main economic activity in the study area, its productivity is insufficient because some of the crops being introduced are not doing well. For this study, three specific objectives were mentioned. These are; identify the suitable area of maize in the study area, identify the unsuitable area of maize in the study area and compare current maize production with suitable and unsuitable area. To accomplish these study four parameters were used such as soil, slope, temperature and rainfall. The parameters were analyzed by ArcGIS 10.3 software. As result the largest portion of the study area was unsuitable for maize production and some part of northern, north western and eastern part of study area was partially suitable for maize production. Finally, we recommended that the concerned bodies should cultivate maize around the suitable part of the study area.
\end{abstract}

Keywords: Debub Gondar, GIS, Maize, Suitability

DOI: $10.7176 /$ JEES/11-4-01

Publication date: April $30^{\text {th }} 2021$

\section{Introduction}

Just like other animals, humans too have to feed on other living organisms in order to survive. This means that as part of the cycle of life, human food is obtained by ending the live of other animals and other living specious [13].

Agriculture being the most primitive occupation of the most civilized mans, draws much on its development starting from shifting cultivation to advanced precision farming, with the advancement in the civilization man come to know about more crops and standard to cultivate many crops. Population increase and advancement in the civilization made man to settle at one place and to cultivate the same place year to year. Now agriculture becomes a profession is given the name commercial agriculture, and precision agriculture, and sustainable agriculture as being the part of it [11].

According to Australia center for international agriculture research, agricultural innovation can improve global food security \& alleviating poverty. Food security challenges have been compounded in recent year by high food prices, natural disasters, conflict and poor governance, and will be further compounded, as global food, fodder, and bioenergy crops, grows climatic variability increase, diet change and natural resource are depleted

Maize is originated at least 5000 years ago in the highlands of Mexico, Peru, Ecuador, and/or Bolivia because of the great density of native forms found in the region. There is evidence that maize from central and South America is introduced to Europe in 1492 by Columbus, and then spread to Africa [8].

Recently, the most important and urgent problem in Ethiopia is to improve agricultural land management with an effective and efficient land-use system for better socio-economic development [1]. The problem of selecting the correct land for the cultivation of a certain agricultural product is a long-standing and mainly empirical issue. According to [7].

Food security in Ethiopia elsewhere in Africa is a major socioeconomic condition. Its economic well-being also dependent on the successes of its agriculture Ethiopia has long suffered from food shortage and economic under development even though it endowed with a wide range of crop and agricultural diversity. Maize, tiff, sorghum, wheat, and barely among cereal's and among root and tubers, inset provide the Maine calorie requirement in Ethiopia diet. Crop productivity and production has been clear sign of change over the past decade [11]. Maize arrived in Ethiopia slightly later around the late $17^{\text {th }} \mathrm{c}$ and was mainly grown as subsistence crop in the mid latitude (1500-2200m) above sea level in southern, south central and south-western part of the country.

Ethiopia is the fifth largest producer of maize in Africa, with the cultivation primarily concentrates in the Amhara, Ormoia and Southern region. In 2012, fiscal year, around 6 million tons of maize was produced, by 9 million farmers across 2 million hectares of land.

According to Debub Gondar agricultural office 20017 report, maize has 54,183 hectares area coverage, while its productivity was 43.31 quintal/hectare. In 2008/9 fiscal year the total product of maize from the above area coverage is $2,347,174$ quintal. 
Multi criteria decision making (MCDM) has been developed to improve spatial decision making when a certain alternative needs to be evaluated on the basis of conflicting and in commensurate criteria [10]. GIS and MCDM can benefit from each other. GIS techniques and producers have an important role to play in analyzing MCDM problems through automating, managing and analyzing a variety of spatial data for decision making. Although an increasing number of GIS are described as systems for supporting spatial decision problems, most of GISs lack the kind of spatial analysis required by decision makers on the other hand MCDM methodologies provide a rich collection of techniques and producers to revel decision makers preferences and to incorporate them in to GIS based decision making. Integration of GIS and RS technologies apart from saving time and yielding food data quality have the ability to locate potential in new crop land sites[9].

\section{General Objective}

The general objective of this study was to carry out agricultural and maize suitability analysis for maize by using GIS and Remote sensing technology. Specifically

a) To identify the suitable and unsuitable area for maize production in the study area

b) To compare current maize production with suitable and unsuitable area

\section{Research Question}

a) How to identify the suitable and unsuitable area for maize production in study area?

b) Compare and contrast current maize production with suitable area?

\section{Materials AND Methodologies}

\subsection{Description of the Study Area}

\subsubsection{Geographical Location}

Debub Gondar is found in Ethiopia Amhara Regional state. Debub Gondar is bordered on the south by Misraq Gojjam, on the south west by mirab Gojjam and Bahirdar, on the west by Lake Tana, on the north by semen Gondar, on the north east by wag Hemra, on the east by semen Wollo, and on the south east by Debub Wollo; the Abay river separate Debub Gondar from the two Gojjam. The absolute location of Debub Gondar is about $11^{\circ} 0^{\prime} 0^{\prime \prime} \mathrm{N}$ to $12^{\circ} 40^{\prime} 0^{\prime \prime} \mathrm{N}$ latitude and $37^{\circ} 20^{\prime} 0^{\prime \prime} \mathrm{E}$ to $39^{\circ} 0^{\prime} 0^{\prime \prime} \mathrm{E}$ longitude.

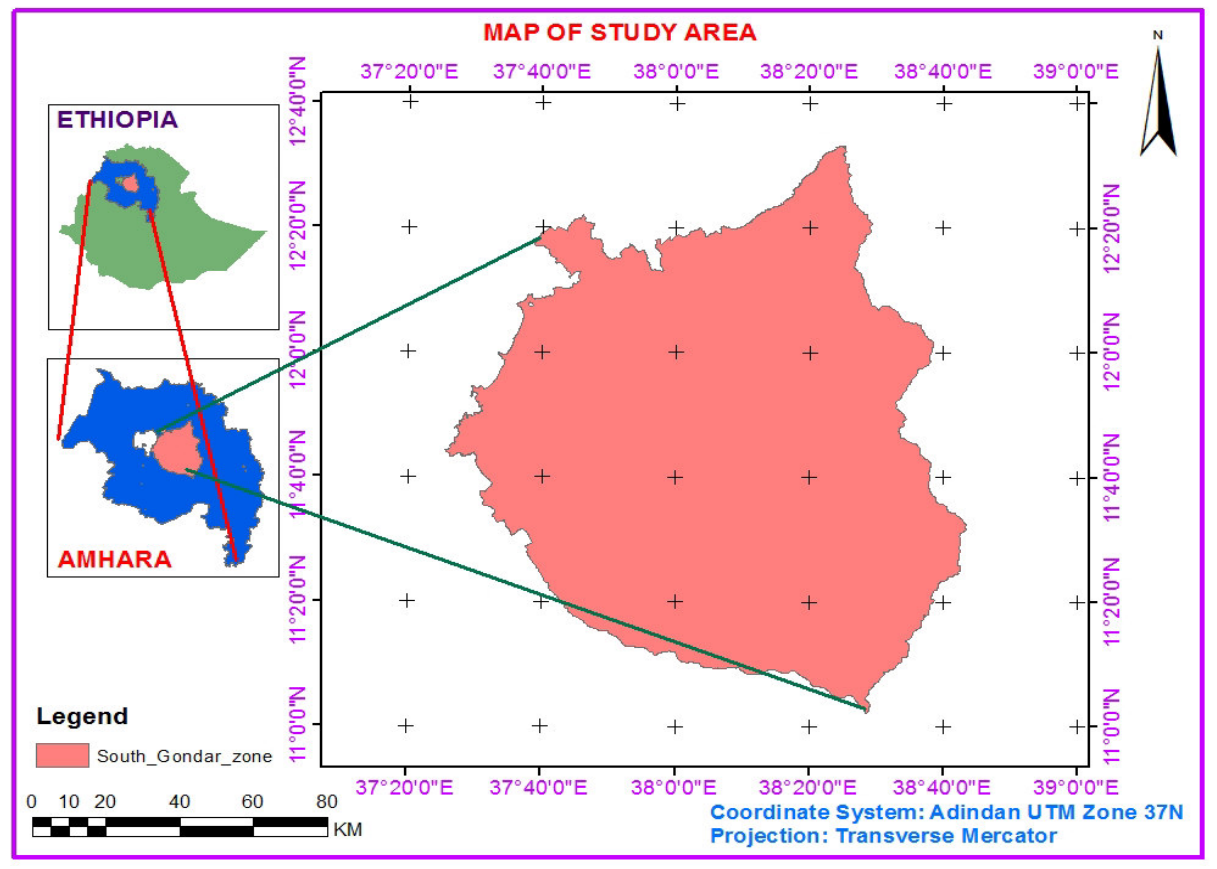

\subsubsection{Climate}

Figure 1. Map of study area.

Debub Gondar zone is located in tropical climate zone which receives seasonal rain fall and characterized by four agro ecological zones. Its agro ecological zone and share of percentage; w/dega (56\%), dega (28\%), kola, $(14 \%)$, and wurch (2\%) with mean annual rain fall $1000-1600 \mathrm{~mm}$ and with average temperature $17^{\circ}$ c to $20^{\circ}$ [4].

\subsubsection{Topography}

Topographically south Gondar zone is characterized by more undulating terrain with significant altitudinal variation ranges from 1500 to $4300 \mathrm{~m}$ above sea level. Percentage share of south Gondar topography are; undulating (75\%), plain (14\%), valley (10\%) and plateau (1\%). It has an average elevation of $2717 \mathrm{~m}$. 


\subsubsection{Demography}

South Gondar zone has a total population of $2,051,738$ and increase of $16 \%$ over the 1994 census, of whom 1,041,061 men and 1,010,677 women with an area of 14,095.19 square $\mathrm{km}$. It has the population density of 145.56: 195.619 or $9.53 \%$ are urban dwellers. A total of 468,238 households were counted in this zone which results in average of $3.8 \%$ to a household and 453,658 housing units. The main ethnic group reported in semen Gondar was the Amhara (99.7\%); all other ethnic group made up of $(0.3 \%)$ of the population Amharic was spoke as the first language by $(99.7 \%)$ the remaining $(0.3 \%)$ spoke all other primary language reported $(96.14 \%)$ practiced Ethiopia orthodox Christianity, and (3.68\%) the population side there were Muslim[3].

\subsubsection{Socio Economic Status}

According to May 24, 2004 World Bank memorandum, (4\%) of the inhabitant of Debub Gondar have access to electricity, this zone has a road density of $66.1 \mathrm{~km}$ per $1000 \mathrm{sqkm}$ (compared to the national average of $30 \mathrm{~km}$, the average rural household are 1 hectare of land (compared to the national average of 1.01 hectare of land and an average of 0.75 for Amhara region), and the equivalent 0.6 heads of livestock. $14 \%$ of the population are non-farm related jobs, compared to the national average of $25 \%$ and regional average of $21 \%$. $49 \%$ of all eligible children are enrolled in primary school and $9 \%$ in secondary school. $55 \%$ of the zone is exposed to malaria and none of test fly [6]. The leading cereal products based on area coverage's are teff, barley, wheat, maize respectively. From total area of $14,095.19 \mathrm{sqkm}$ only $551,078 \mathrm{sqkm}$ is suitable for agriculture [4].

\subsection{Research Design}

In order to accomplish this study the researcher was used quantitative research design. All the data was quantified like soil, topography, DEM, and climate data related with suitability for maize production and expressed in percent.

\section{Material and Methods}

To conduct this study the researcher was used digital material (computer and mobile phone) and ArcGIS software in order to collect data from different source and analysis the collected data.

\section{Data Source and Methods of Data Collection}

Data for this study was collected from both primary and secondary data source. The primary data was collected through interview from the concerned bodies such as DGAO. Secondary data was collected from published reference books and unpublished materials like annual reports. Such as soil and DEM data were obtained from DTU GIS lab room, climate data (temperature and rain fall) was collected from metrology station.

\section{Method of Data Processing and Analyzing}

To achieve the stated objectives and research question the researcher was applied analysis through interpolation (IDW), reclassify and fuzzy overlay.

\section{Parameter Specification}

The parameters for this study were soil type, rainfall, minimum temperature, maximum temperature, slope and elevation. Six criteria were selected for evaluating land suitability for maize crop in the study area. These criteria were selected based on extensive literature review of potential factor affecting.

\section{Model Validation}

\subsection{Soil Type Validation}

The major soils which support the growth of maize are ferralsols, nitosols, acrisols, arenosols, cambisols and lithosols [15].

Table 1. Soil type validation.

\begin{tabular}{lll}
\hline Class & Soil type & Description \\
\hline $\mathrm{S}$ & Nitosols, lithosols, and cambisols & Suitable for maize cultivation \\
$\mathrm{U}$ & Vertisols, Luvisols, Rock Surface, Regosols and Lake & Unsuitable for maize cultivation \\
\hline
\end{tabular}

\subsection{Rainfall Validation}

Maize is grown mostly region having annual rainfall between $600 \mathrm{~mm}$ and $1100 \mathrm{~mm}$. [16]

Table 2. Rainfall validation.

\begin{tabular}{lll}
\hline Class & Rainfall $(\mathbf{m m})$ & Description \\
\hline $\mathrm{S}$ & $600-1100$ & Suitable for maize cultivation \\
$\mathrm{U}$ & $<600$ and $>1100$ & Unsuitable for maize cultivation \\
\hline
\end{tabular}




\subsection{Slope Validation}

A place which has less than $25 \%$ of slope is suitable, whereas a very steep slope of more than $25 \%$ is unsuitable for maize production (www.esdac.jrc.ec.europa.

Table 3. Slope validation

\begin{tabular}{lll}
\hline Class & Slope $\mathbf{( \% )}$ & Description \\
\hline $\mathrm{S}$ & $<25$ & Suitable for maize cultivation \\
$\mathrm{U}$ & $>25$ & Unsuitable for maize cultivation \\
\hline
\end{tabular}

\subsection{Elevation Validation}

Maize is grown chiefly between elevation of 1500 and $2200 \mathrm{~m}$ and require large amount of rainfall to ensure good harvest [5].

Table 4. Elevation validation.

\begin{tabular}{lll}
\hline Class & Elevation $(\mathbf{m})$ & Description \\
\hline $\mathrm{S}$ & $1500-2200$ & Suitable for maize production \\
$\mathrm{U}$ & $<1500$ and $>2200$ & Unsuitable for maize production \\
& & \\
\hline
\end{tabular}

\subsection{Temperature Validation}

The maximum temperature for maize growth and development is less than $32^{\circ} \mathrm{C}$, whereas the minimum temperature for maize growth and development is below $8^{\circ} \mathrm{c}[2]$.

Table 5. Temperature validation.

\begin{tabular}{llll}
\hline Class & Maximum temperature $\left({ }^{\circ} \mathrm{C}\right)$ & Minimum temperature $\left({ }^{\circ} \mathrm{C}\right)$ & Description \\
\hline $\mathrm{S}$ & $<32$ & $>8$ & Suitable for maize cultivation \\
$\mathrm{U}$ & $>32$ & $<8$ & Unsuitable for maize cultivation \\
\hline
\end{tabular}

\section{Model Type}

The above parameters were overplayed by fuzzy overlay technique. This tool is recommended for the use with the result of the fuzzy membership tool. It is meant to be applied to raster's with values that range between 0 and 1.

\section{Analysis and Interpretation}

\subsection{Maize Suitability Analysis Based on Soil Type}

From the above result (figure 2), the classified map of the study area consists of suitable and unsuitable land for maize production based on soil. The black color indicates suitable area where as the white color represent unsuitable area for maize production. As a result show that, in terms of soil type the suitable area are located to some part of north, south, east, north east and south east part of the study area. The unsuitable area also located to west and central part of the study area.

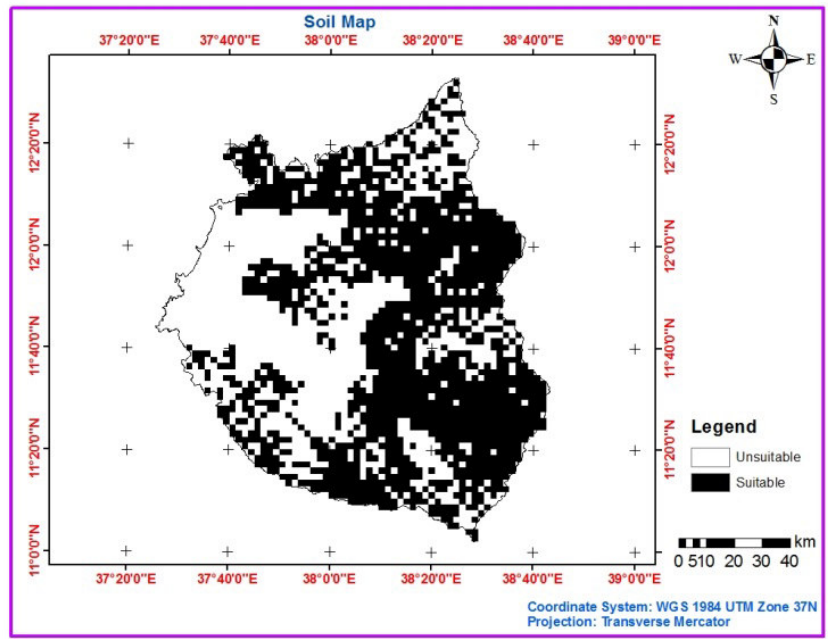

Figure 2. Maize suitability classification based on soil type. 
Table 6. Maize suitability classification based on soil type.

\begin{tabular}{|c|c|c|c|c|}
\hline Class & Range of soil type & Color & Area (ha) & $\begin{array}{l}\text { Percentage } \\
\text { coverage }(\%)\end{array}$ \\
\hline Unsuitable & $\begin{array}{l}\text { Vertisols, Luvisols, Rock Surface, Regosols } \\
\text { and Lake and other }\end{array}$ & White & 606367 & $43 \%$ \\
\hline $\begin{array}{l}\text { Suitable } \\
\text { Total }\end{array}$ & nitosols, cambisols, and lithosols & Black & $\begin{array}{l}802477.4 \\
1408844.4\end{array}$ & $\begin{array}{l}57 \% \\
100 \%\end{array}$ \\
\hline
\end{tabular}

As table 6 shows that, $57 \%$ of soil types were suitable and the remaining $43 \%$ were unsuitable for maize production in the study area.

\subsection{Maize Suitability Analysis Based on Rainfall}

Form the above result, the classified map of the study area consists of suitable and unsuitable area for maize production. The black color represents suitable area and white color also indicates the unsuitable area for maize. From this the northern and some part of eastern area are suitable, whereas southern, south eastern, south western, and some part of north eastern area of the study area unsuitable for maize in terms of rainfall.

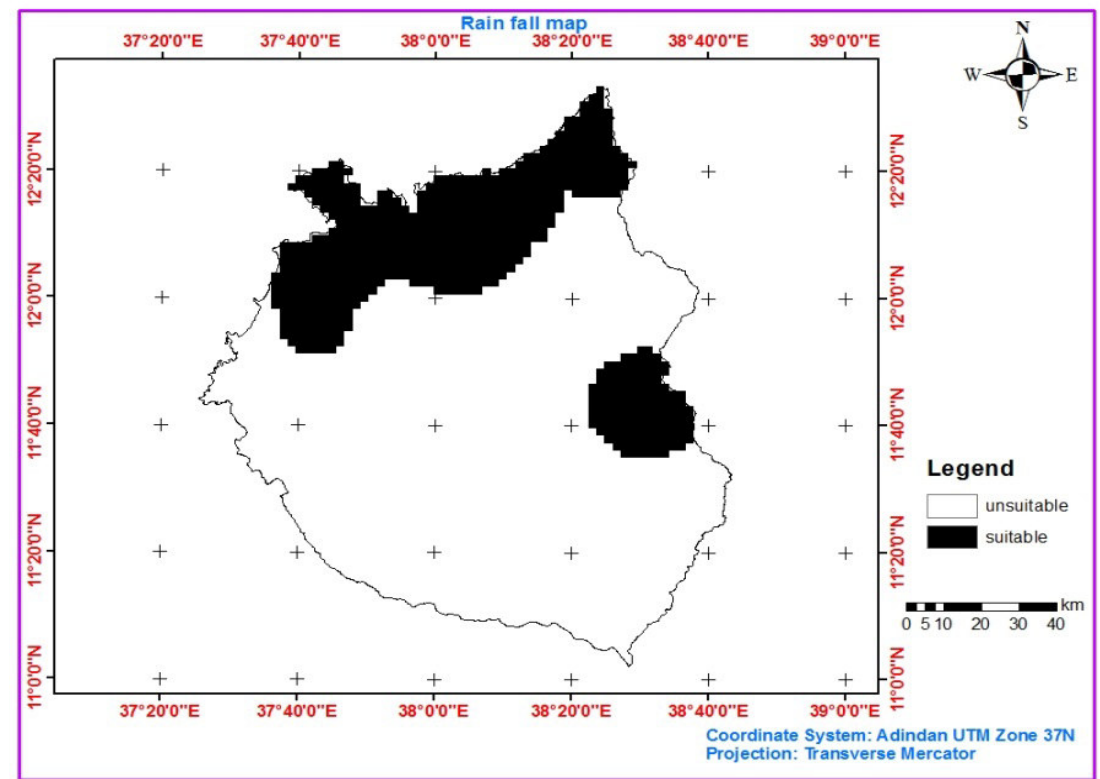

Figure 3. Maize suitability classification based on rainfall.

Table 7. Maize suitability classification for maize based on rainfall.

\begin{tabular}{lllll}
\hline Class & Range of Rainfall & Color & Area (ha) & Percentage of coverage (\%) \\
\hline Unsuitable & Below 600mm and above 1100mm & White & 1051267.4 & $75 \%$ \\
Suitable & Between 600mm-1100mm & Black & 357577 & $25 \%$ \\
Total & & & 1408844.4 & $100 \%$ \\
\hline
\end{tabular}

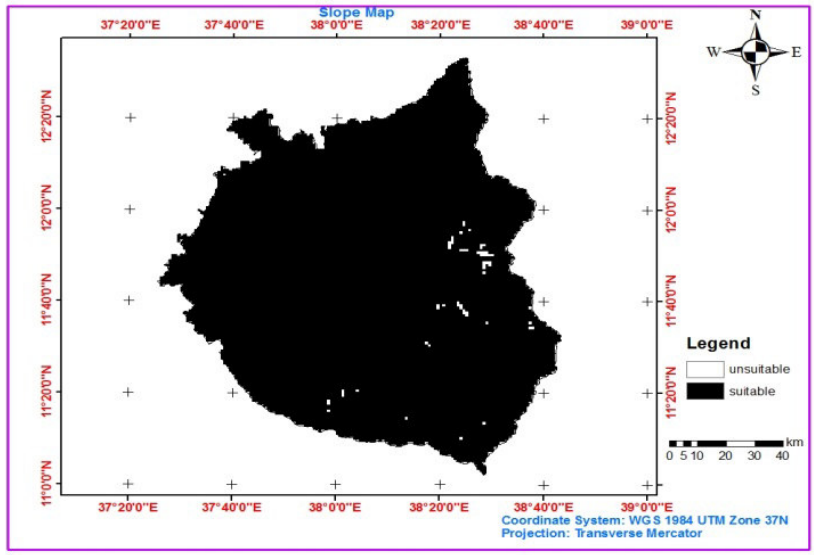

Figure 4. Maize suitability classification based on slope. 
As the above table 3 showed that, the greatest portion of the study area was unsuitable for maize production in terms of rainfall amount, which shares $75 \%$ from the total and the remaining $25 \%$ was suitable for maize cultivation.

\subsection{Maize Suitability Analysis Based on Slope}

From the above map, the classified map of study area consists both suitable and unsuitable area for maize production. Black color indicates the suitable area whereas the white color represents the unsuitable area for maize production. The classified map shows that, much of the study area were suitable for maize based on slope and little portion of the study area were unsuitable, which located eastern and southern part of the study area.

Table 8. Maize suitability classification based on slope.

\begin{tabular}{lllll}
\hline Class & Range of slope & Color & Area (ha) & Percentage coverage (\%) \\
\hline Unsuitable & Above $25 \%$ & White & 6117.431 & $0.44 \%$ \\
Suitable & $0-25 \%$ & Black & 1402727 & 99.56 \\
Total & & & 1408844.43 & $100 \%$ \\
\hline
\end{tabular}

As table 4 , shows that the most dominated areas of the study area was suitable which share $99.56 \%$ from the total and the remaining $0.44 \%$ was unsuitable for maize production based on slope parameter.

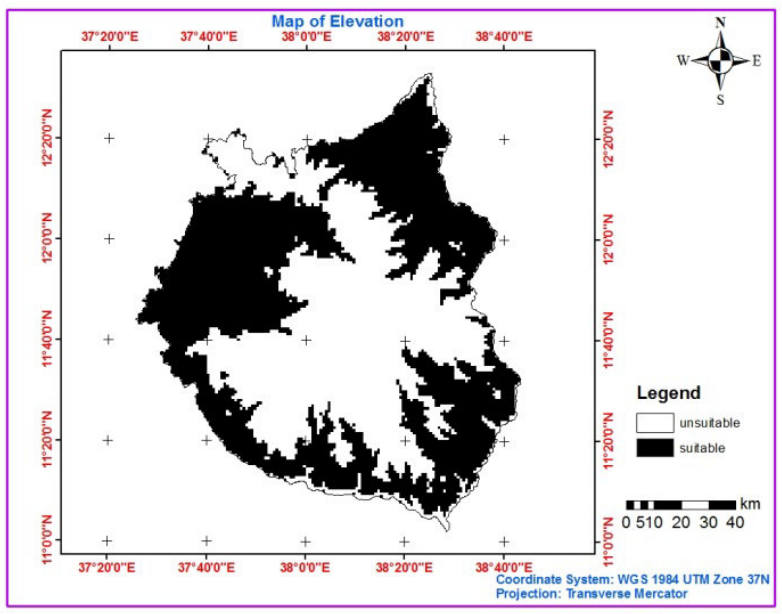

Figure 5. Maize suitability classification based on elevation.

\subsection{Maize Suitability Based on Elevation}

According to figure 6, suitable which represented by black color and unsuitable area which represented by white color. The suitability area for maize based on elevation is located as western, southern, north eastern and southwestern part of the study area and unsuitable area for maize is also located most central part and some part of north of the study area based on elevation.

Table 9. Maize suitability classification based on elevation.

\begin{tabular}{lllll}
\hline Class & Range of Elevation & Color & Area (ha) & Percentage share from the total \\
\hline Unsuitable & Below 1500m and above 2200m a.s.1 & White & 652118.1 & $46.3 \%$ \\
Suitable & Between 1500-2200m a.s.1 & Black & 756726.3 & $53.7 \%$ \\
Total & & & 1408844.4 & $100 \%$ \\
\hline
\end{tabular}

As depicted from table 5, the largest portion of the study area was suitable that shares $53.7 \%$ and $46.3 \%$ the remaining $46.3 \%$ was unsuitable for maize production based on elevation.

\subsection{Temperature requirement for maize production}

Normally the temperature goes down with increasing altitude. Sometimes, a "temperature inversion" happens where the temperature goes up with increasing altitude. At the troposphere the temperature starts to go up with increasing altitude [26].

\subsection{Maize suitability based on minimum temperature}

As the above map dipicted that, the suitable area represented by black color and white color show the unsuitable area for maize production. As the result show that the suitable area located North, West, South, Southwest, Southeast and Northeast whereas unsuitable area found around Northwest, East, and Centeral part of the study area based on minimum temprature. 


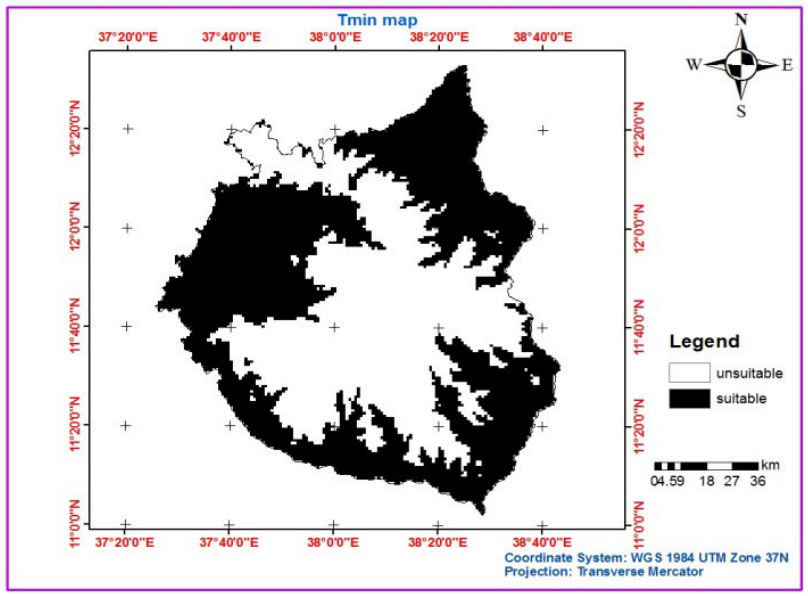

Figure 6. Maize suitability classification based on Tmin.

Table 10. Maize suitablity classification based on Tmin.

\begin{tabular}{|c|c|c|c|c|}
\hline Class & $\begin{array}{l}\text { Range of minimum } \\
\text { temperature }\end{array}$ & Color & Area (ha) & $\begin{array}{l}\text { Percentage share from the } \\
\text { total area }(\%)\end{array}$ \\
\hline Unsuitable & Below $8^{\circ} \mathrm{c}$ & White & 628464.1 & $44.6 \%$ \\
\hline Suitable & Above $8^{\circ} \mathrm{c}$ & Black & 780380.3 & $55.4 \%$ \\
\hline Total & & & 1408844.4 & $100 \%$ \\
\hline
\end{tabular}

As table 6 shows that, $55.4 \%$ of the study area was suitable for maize production, where as $44.6 \%$ of the study area was unsuitable for maize production based on minimum temprature.

\section{7. maize suitability based on Maximum Temprature}

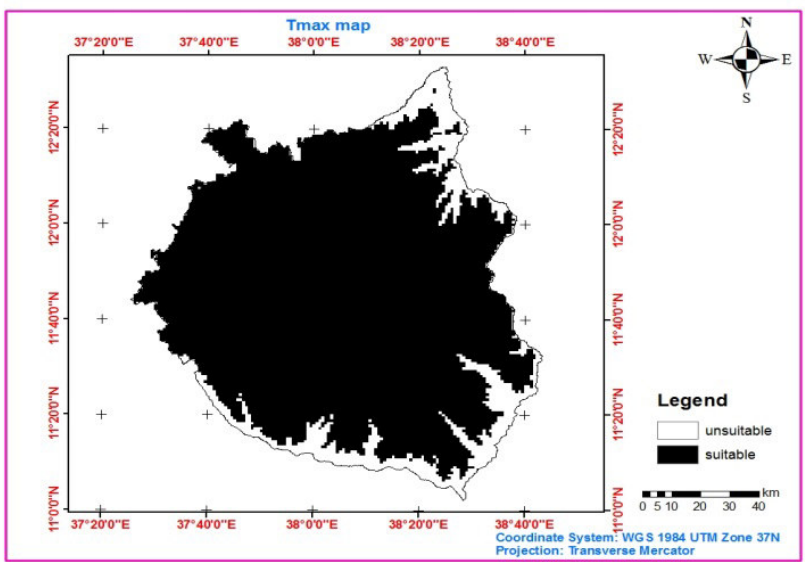

Figure 7. Maize suitability classification based on maximum temperature.

As the above map showed that, large portion of the study area was suitable for maize production based on maximum temperature. The black color represents the suitable area and the white indicate unsuitable area for maize. From this, the suitable area for maize was located as eastern, north eastern and central part of the study area suitable for maize based on maximum temperature, and unsuitable area for maize production based on maximum temperature is located southern, south western and north western peripheral area of the study area.

Table 11. Maize suitability classification based on maximum temperature.

\begin{tabular}{llllll}
\hline Class & $\begin{array}{l}\text { Range of } \\
\text { temperature }\end{array}$ & maximum & Color & Area(ha) & $\begin{array}{l}\text { Percentage share from the } \\
\text { total }\end{array}$ \\
\hline $\begin{array}{l}\text { Unsuitable } \\
\text { Suitable }\end{array}$ & Above $32^{\circ}{ }_{c}$ & Below $32^{\circ}{ }_{\mathrm{c}}$ & White & 163641.4 & $12 \%$ \\
Total & & Black & 1245203 & $88 \%$ \\
\hline
\end{tabular}

As table 11 depicted that based on maximum temperature the large area was suitable for maize which shares $88 \%$ from the total area. The remaining $12 \%$ was unsuitable for maize.

\section{Comparison of Maize Suitability with current production}

According to DGAO 2009 report, in 2016/17 fiscal year maize has 54,183 ha area coverage with 2,343,174 
quintal production. Its productivity was also 43.31 per hectare. According to this study suitable area for maize production was 1,133,965 hectare from the total study area. This indicates that 59782 hectare was not used from the total suitable area for maize production. Which show that only $47.8 \%$ of suitable area was used for maize cultivation.

\section{Interpretation}

For this study six variables were used these were soil type, rainfall, slope, elevation Tmax and Tmin. Each variable has its own parameters. Therefore, the suitable ranges for maize production were soil type (nitosols, cambisols, and lithosols), rainfall (600mm-1100mm), Elevation (1500m-2200m), Slope (Up to 25\%), maximum temperature $\left(32^{\circ} \mathrm{c}\right)$, and minimum temperature above $\left(8^{\circ} \mathrm{c}\right)$.

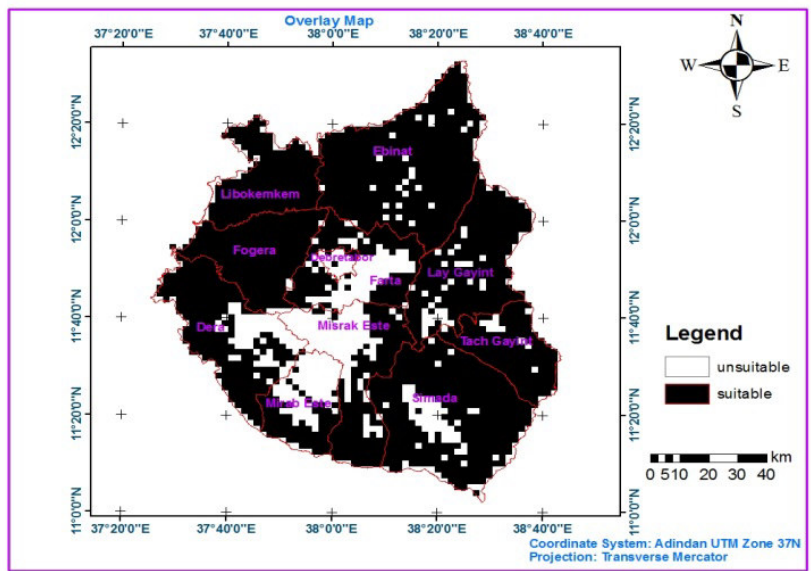

Figure 8. Overlay maize suitability.

From the above map the black color represent the suitable and the white color indicate the unsuitable area for maize production. As the result of above map shows that, Libokemkem and Fogera district are mostly suitable for maize, and Ebinat Lay Gayint, Tach Gayint, Simada, Dera, are most suitable whereas the remaining Mirab Este, Misrak Este, farta, and Debre Tabor are mostly unsuitable district for maize production based on overlays.

Table 12. Overlay maize suitability classification.

\begin{tabular}{llll}
\hline Class & Color & Area (ha) & Percentage of coverage (\%) \\
\hline Unsuitable & White & 274879.4 & $20 \%$ \\
Suitable & Black & 1133965 & $80 \%$ \\
Total & & 1408844.4 & $100 \%$ \\
\hline
\end{tabular}

As illustrated ontable8, the suitable area was much greater than unsuitable area which share $80 \%$ and unsuitable area share $20 \%$ from the total area for maize cultivation.

\section{Conclusions}

The research has undertaken to identify the suitable and unsuitable land for maize production by using GIS technology in Debub Gondar zone, Amhara region, Ethiopia. GIS functionality can play a major role in spatial decision making. Considerable effort was involved in information collection for the suitability analysis for crop production.

Therefore, by using this spatial analysis, this study was analyzed based on different variables such as soil type, elevation, slope, rainfall, minimum temperature, and maximum temperature. According to this study, 57\% of soil type, $25 \%$ of rainfall, $53.7 \%$ of elevation, $99.5 \%$ of slope, $55.4 \%$ of minimum temperature, and $88 \%$ of maximum temperature were suitable for maize production, whereas $43 \%$ of soil type, $46.3 \%$ of elevation, $75 \%$ of rainfall, $0.44 \%$ of slope, $22 \%$ of maximum temperature, and $44.6 \%$ of minimum temperature were unsuitable for maize production.

From the finding $80 \%$ of Debub Gondar zone area coverage is suitable more maize cultivation, whereas the remaining $20 \%$ area coverage is unsuitable for maize cultivation.

Based on district level, the areas which were suitable for maize are some part of Ebinat, Libokemkem, Fogera, lay Gayint and Tach Gayint, and the reaming districts such as Mirab Este, Misrak Este, Farta, Simada, Dera, and Debre Tabor were mostly unsuitable totally.

\section{Recommendation}

Standing from the result of this study, and the finding that was done and some possible recommendations are; to alleviate poverty and ensure food security in the study area, government and agricultural experts should take 
their responsibilities by giving appropriate training for local farmers. The local government may use the result of this study to advice the local farmers on the suitable area for maize cultivation. According to the study, local farmers who live around the suitable area that contains 1133965 hectares should practice maize cultivation.

\section{References}

[1] Abera, H. B. (2008). Adoption of improved tef and wheat production technologies in crop-livestock mixed systems in northern and western Shewa Zones of Ethiopia (Vol. 2010). University of Pretoria.

[2] CJ Birch, J Vos, J Kiniry, HJ Bos, Elings. (1998). Filed crop research (59) (3), 187-200

[3] CSA. (2007) population census of the federal democratic republic of Ethiopia. Centeral statistical agency

[4] Debub gonder agricultural office report 2017

[5] Dereje G. and Eshetu A. (2011). Crop and agroecological zone of Ethiopia senior researchers, Ethiopian institute of agricultural research.

[6] Ethiopia second road sector development program project, p3 ( world bank project appraisaldevelopment published 19 may 2003

[7] Girma \& kanate. (2017). GIS-Based land-use suitability analysis for selected perennial crops in Gumay Woreda of Jimma Zone, South West Ethiopia. Ethiop. j.soc.lang.stud, 4(1), 3-18.

[8] International institute of tropical agriculture. (1982). Maize production manual.

[9] John Wiley \& Sons Inc. (2006). Regration analysis by example $4^{\text {th }}$ edition published simultaneously in caudal

[10] Leingsakul, M. Mekppaibooniwatana, K. Borniveld, \& H, Huizing. (1993). Use of GIS and remote sensing for soil mapping for location new sites for permanent crop land a case study in a highland of north Thailand Marble, D. calkins, A., \& D. J. Refuet. (1984). Bornic readings in GIS.

[11] Malczewski, J. (2004). GIS based land used suitability analysis: a critical over view. Program. Plan 62(1), 33-65.

[12] Prakash, T. N. (2003). Land suitability analysis for agricultural crops: fuzzy multi criteria decisionmaking Approach

[13] Robert, M. (2007). Solar cell research at IOWA state university.

[14] Stibbe A. (2015). Critical discourse analysis and ecology: the search for new stores to live by.

[15] www.fao.org/docrep/t1996e07.htm.

[16] www.yourarticleliberary.com/maizeproduction: production and distribution of maize around the world 